\title{
THE INFLUENCE OF ABDUH'S PRINCIPLE ON RASHID RIDA
}

\author{
Ahmad Nabil Amir \\ International Institute of Islamic Thought and Civilization (ISTAC- \\ IIUM) International Islamic University Malaysia, Kuala Lumpur \\ nabiller2002@gmail.com
}

\begin{abstract}
This paper analyze the influence of Muhammad 'Abduh on his chief disciple, Muhammad Rashid Rida. Rida was the leading advocate of Abduh's rational principle and modern ideas through his writing in Tafsir al-Manar (The Manar Commentary) and Tarikh al-Ustadh al-Imam Mubammad Abdub (Biography of Mubammad Abdub). Tafsir al-Manar is a Qur'anic exegesis based on rational approach outlined by Muhammad 'Abduh and the Tarikh is a comprehensive biography of the life and works of Muhammad Abduh printed in three volumes that significantly documented Abduh's lasting influence and legacy in modern Egypt. Rida continued to resolutely champion the ideas of reform through Majallat al-Manar (al-Manar Journal) that highly reverberated Abduh's principles and remarkably claimed extensive influence in contemporary Islamic world.
\end{abstract}

Keywords: Muhammad Abduh, Muhammad Rashid Rida, idealism and influence, modern Islam

\section{Introduction}

The influence of Muhammad Abduh (1849-1905) on Muhammad Rashid Rida (1865-1935) was intensely profound. Abduh's tremendous 
impact in modern world and his significant influence were partly due to the far-reaching and monumental efforts of Rashid Rida to promulgate and extend his ideas to various corners and frontiers of Islamic world. Abduh's dynamic aspiration of Islamic reform was significantly expanded by Rida in his famous periodic al-Manar (1898-1935), and in his phenomenal and encompassing work, the Tarikh al-Ustadh al-Imam Mubammad Abduh, the pioneering work which compiled a detail and comprehensive biography of 'Abduh in three substantive volumes. This outstanding legacy was depicted by Malcolm Kerr in his definitive work, Islamic Reform: The Political and Legal Theories of Mubammad 'Abduh and Rashid Rida: "Rida devoted most of his career to propagating a revivalist interpretation of Islamic faith and institutions... He wrote much more voluminously than his master. He elaborated a doctrine of Islamic law and politics much more systematic and specific than anything "Abduh had attempted." 1

\section{Abduh's influence in tafsir}

Abduh's unfinished commentary, Tafsir al-Manar (al-Manar Commentary) was the most influential and definitive work of tafsir that manifested his immense influence on Rida. It was compiled by Rida from Qur'anic dictates and lectures delivered by Abduh at Jami' al-Azhar, 2 from first Muharram $1317 \mathrm{AH} / 1899$ AD until the mid of Muharram $1323 \mathrm{AH} / 1905 \mathrm{AD}$. The lecture later appeared in Egyptian's official newspaper al-Mua'yyid in a series of articles wrote by Rida, entitled "alQur'an". Abduh explained the text from Sura al-Fatihah until Sura al-Nisa' verse 125 , and this was substantially expanded with notes by Rida. He used to refer the commentary to Abduh and his views in compiling it, and after making some checking and revision, it was serialized in alManar.

After the death of Abduh in 1905 Rida continued the effort of assembling and making the tafsir. He commented from sura al-Nisa' verse 126 until Sura Yusuf (as) verse 101 (My Lord, You have given me [something] of sovereignty and taught me of the interpretation of dreams) and he referred to it as Tafsir al-Qur'an al-Hakim li al-Ustadh Muhammad 'Abduh indicating its origin from the Imam. It was commenced in Bombay, India at the beginning of Rabi' al-Akhir 1330

\footnotetext{
${ }^{1}$ Malcolm Kerr, Islamic Reform: The Political and Legal Theories of Muhammad 'Abduh and Rashid Rida (Berkeley, Los Angeles: University of California Press, 1966), 153.

2 'Abd al-Qadir Zimamah, et al. Mujam Tafsir al-Qur'an al-Karim (N.p.: Mansyurat alMunazzamah al-Islamiyyah li al-Tarbiyyah wa al-'Ulum wa al-Thaqafah (ISESCO), 1997), 335. 
AH until his death in 1345/1935 which spanned about 30 or 35 years. Rida's work was continued by Shaykh Muhammad Bahjat al-Baytar after his death in 1935, commenting on Sura Yusuf (as) from verses 102 until 111 and published separately under the authorship of Rida entitled Tafsir Sayyid Muhammad Rashid Rida. ${ }^{3}$ In 1984, Qadi Muhammad ibn Ahmad Kan'an of Lebanon summarized the Tafsir (al-Mukbtasar) and published it in Beirut in three volumes. ${ }^{4}$

Rida's distinguished effort in compiling, summarizing and expanding the work was depicted in his explanation of Sura al-Nisa' that clearly illustrated his effort in extending 'Abduh's legacy: "So here end the teaching of al-Ustadh al-Imam and we will continue with attempt to complete the interpretation if God will based on the method and guidance we acquired from him, though we did not able to interpret all the verses comprising of juristic instruction and lesson. It is a divine gift abundantly vouchsafed on his perceptive mind which enable him to grasp and interpreted the verses of al-Qur'an steadily except the last chapter of 30 which he interpreted briefly." 5

Rida's commentary closely followed the traditional style of sharh, discriminating and distinguishing his saying from the explanation of the Imam, by denoting in the tafsir, qala al-ustadh al-imam (the teacher-imam says), qala ma ma'nabu (he says - concerning its meaning) summarizing Abduh's views, and marks his own work with the statements, aqul (I say), and "written by Muhammad Rashid Rida", as depicted by J. Jomier in his incisive article on 'al-Manar': "[Tafsir al-Manar] from the third year onward was the work of Rashid Rida; it included lengthy extracts from the commentary expounded by Muhammad 'Abduh in the evening lectures at al-Azhar, and the respective contributions of the two men were clearly distinguished." ${ }^{6}$ This method was consistently followed in the tafsir, as illustrated in his commentary of Sura Al-Imran [3: 110]: (You are the best community that has been raised up for mankind),

\footnotetext{
${ }^{3}$ Al-Dhahabi, Muhammad Husayn, Al-Tafsir wa'l-Mufassirun (Cairo: Dar al-Kutub alHadithah, 1976), 42.

${ }^{4}$ Abd al-Qadir Zimamah, et al. Mu'jam Tafsir al-Qur'an al-Karim (N.p.: Mansyurat alMunazzamah al-Islamiyyah li al-Tarbiyyah wa al-'Ulum wa al-Thaqafah (ISESCO), 1997), 340.

${ }^{5}$ Muhammad Rashid Rida, Tafsir al-Manar (Beirut: Dar al-Kutub al-'Ilmiyyah, 1999), $5 / 356$.

"J. Jomier, "Al-Manar" in Encyclopaedia of Islam 2, VI, 1991), 361, Kosugi Yasushi, "AlManar revisited: the "lighthouse" of the Islamic revival" in Stephane A. Dudoignon, Komatsu Hisao, Kosugi Yasushi (eds.), Intellectuals in the Modern Islamic World Transmission, Transformation, Communication (London and New York: Routledge, 2006), 36.
} 
"The essence of what the teacher-imam ['Abduh] said is: this description [of the best community] is true about those to whom it was first addressed. They were the Prophet (saw), may Allah bestow blessings and peace upon him, and his companions upon them be Divine satisfaction. They were once enemies, but God united their hearts so that, by Divine Grace, they became brothers. And they were those who tied each other by the Divine rope [Islam] and were not disunited in religion to become partisans of particular sects, and they were those who were ordering the good and forbidding the evil." 7

Abduh's continues to portray the exemplary conducts and excellent merits of the companions and Rida accentuated this point by giving his significant comment: "I say: this is the summary meaning of what the teacher-imam said, except the phrase "and his companions who were with him" [which needs an explanation]. This is from his words, but he intended these noble attributes and perfect characteristics for that perfect faith not for everyone for whom the hadith scholars apply the term of a companion, such as a Bedouin who just embraced Islam and saw the Prophet (saw) only once..." 8

The commentaries wrote by Rida focused on the function of the Qur'an as ultimate guidance for mankind. It executed and transformed new understanding of the text, emphasizing the Qur'an as the principal source of Islamic theology and jurisprudence, and critically selecting the source of hadith and denouncing the Isra'iliyat tradition, expanding modern rational worldviews and taking critical position on Islamic intellectual heritage.

In formulating and constructing the method and propounding its argument, it aspired to form a modern and scientific commentary of the Qur'an, by explaining the Qur'an from a modernist perspective. It places great emphasis on reason, as "the key to understanding the meaning of its text" " and developed crucial analysis of the text from modern viewpoints reflecting its relevancy to contemporary world.

The work was highly acclaimed as one of the greatest work of exegesis in modern time, as signified by Abdullah Saeed in his concise

\footnotetext{
${ }^{7}$ Rida, Rashid, Tafsir al-Qur'an al-Hakim al-mushtahar bi ism Tafsir al-Manar (Cairo: Dar alManar, 1947), 4/48.

8 Ibid.

9 Abdin Chande, "Symbolism and Allegory in the Qur'an: Muhammad Asad's Modernist Translation" in Islam and Christian-Muslim Relations, 2004, 15 (1), 79-89.
} 
work on the Qur'an, investigating its history, and key aspects of its understanding and interpretation, The Qur'an: An Introduction: "One of the best-known modernist writings is Muhammad Abduh's Tafsir al-Manar, which was compiled and completed after Abduh's death by Rashid Rida (d. 1935), a student of Abduh." ${ }^{10}$ It was hailed as the modern sunni interpretation which represent a rational and balanced commentary, and strongly defend Islamic ideology and challenging the western missionary campaign, as emphasized by Mahmoud Ayoub in his work The Qur'an and Its Interpreters: " Abduh interpretation is a modern sunni tafsir [which] appeared in the $19^{\text {th }}$ century as a reaction to the challenge of western technology, science and education. It was rational and apologetic; its primary aim was to present Islam to Muslims and defend it against the western secular and missionary onslaughts." 11

The explanation of the verses began with comprehensive discussion on the verses, the meaning of particular words, historical account of the circumstances of its revelation, and the context of the ayah, its legal implications and significant lesson drawn from it. It employed decisive method of al-adabi al-ijtima'i (ethical and social interpretation $)^{12}$, emphasizing the dimension of social and rational understanding of the text, as depicted by Kosugi Yasushi, "Tafsir alManar is an attempt to justify the reformulation of Islamic understanding of faith, society, life, and the world in modern days with its readings of the Qur'anic passages." 13

It was first serialized in al-Manar's magazine in 1901 (vol. 4), and had momentous impact on the rationalist commentary developed by the Manarist party. The commentary fundamentally based on critical method of "the rational and social school (al-madrasa al-aqliya al-ijtima'iyya) ${ }^{14}$, advocating reason and coherent approach (ittijah 'aqli tawfiqi) ${ }^{15}$ and balanced (mu'tadi) commentary ${ }^{16}$. It marshaled scientific arguments "in the light of the underlying Qur'anic message as it is revealed in its ethical and social teachings". ${ }^{17}$ Its comprehensive principle was informed in the

\footnotetext{
10 Abdullah Saeed, The Qur'an An Introduction (Oxford: Routledge, 2008), 209.

${ }^{11}$ Mahmoud Ayoub, The Qur'an and Its Interpreters, vol. I (Albany: State University of New York Press, 1984), 39.

12 Dhahabi, 1976, 2/547, op.cit.

${ }^{13}$ Kosugi Yasushi, 2006, 17, op.cit.

${ }^{14}$ Al-Rumi, Fahd b. 'Abd al-Rahman b. Sulayman, Ittijahat al-Tafsir fi al-Qarn al-Rabi' 'Ashr, 4th ed. (Riyad: Maktabah al-Rushd, 2002), 703.

15 Al-Muhtasib, 'Abd al-Majid 'Abd al-Salam, Ittijahat al-Tafsir fi al-'Asr al-Rabin (Beirut: Dar al-Bayariq.Al-Muhtasib, 1982), 101.

${ }^{16}$ Kosugi Yasushi, 2006, 28, op.cit.

17 Abdin Chande, 2004, op.cit.
} 
introduction: "This is the only interpretation that combined transmitted tradition (al-ma'thur) of interpretation which is authentic with rational interpretation (al-ma'qul) which is sarib (obvious), explaining the law (shariah), and established order (sunan) of God in man's life, and the fact that al-Qur'an is a guidance to people in every place and time, and weigh between its revelation and human condition in this time. And that they have discarded it, and the state of the salaf (righteous forbearers) those who hold tightly to its rope, with the ease of expression, and dispense away discourse related to terminology of science and art, in a way that is understood by the laymen, and equally imperative for the adept. So this is the course that was followed when delivering his lecture in Jami' alAzhar by Hakim al-Islam al-Ustadh al-Imam al-Shaykh Muhammad "Abduh." 18

There were certain disputes on the origin of this work. Ignaz Goldziher, and Joseph Schacht, attributed its origin to 'Abduh. Others contended that it was prepared by an assembly of scholars undertaking to accomplished it. M. Quraish Shihab (b. 1944) in his critical study of Tafsir al-Manar, (Rasionalitas al-Qur'an: Studi Kritis Tafsir al-Manar) claimed that the work was initially constructed by the three men, Al-Afghani, Abduh and Rida, contending that: "this interpretation of the book is basically a work of three prominent and leading exponents of modern Islam, Sayyid Jamaluddin al-Afghani, Syaikh Muhammad Abduh, Sayyid Muhammad Rasyid Ridha. Al-Afghani inspired and spread the idea of renewal, which is, refined and delivered through interpretation of the verses of the Qur'an by M. Abduh. Rasyid Ridha wrote all the ideas articulated by his comrade and teacher in the form of summaries and explanations." ${ }^{19}$ But in J. Jomier's opinion, Rida's contributions form the basis of the work ${ }^{20}$, and this position was reinforced by Charles $\mathrm{C}$. Adams, suggesting the same proposition in his book, Islam and Modernism in Egypt: A Study of the Modern Reform Movement Inaugurated by Mubammad Abduh: "and its preparation [The Manar Commentary] has been due, to so large an extent, to the labours of the editor of Al-Manar." ${ }^{21}$ After all, it is clear that Rida was the principle exegetes who had extensively

\footnotetext{
${ }_{18}$ Rida, 1947, 1, op.cit.

${ }_{19}$ M. Quraish Shihab, Rasionalitas al-Qur'an: Studi Kritis atas Tafsir al-Manar (Bandung: Pustaka Hidayah, 1994).

${ }^{20}$ Jomier, Jacques, Le Commentaire Coranique du Manar (Paris: G.P. Maisonneuve \& Cie, 1954), 143.

${ }^{21}$ Charles C. Adams, Islam and Modernism in Egypt: A Study of the Modern Reform Movement Inaugurated by Muhammad 'Abduh (London: Oxford University Press, 1933), 198.
}

124 Ahmad Nabil Amir - The Influence Of Abduh's 
commented "almost eight suras or two third" 22 of the whole tafsir, as pointed out by Jane McAuliffe that "Tafsir al-Manar is largely Rida's work." 23

Rida advocated Abduh's rational principle in understanding the Qur'an, focusing on its function as religious book intended to guide man towards happiness in this world and the hereafter. ${ }^{24}$ This paramount and fundamental aspiration was significantly outlined by Abduh in his introduction: "the tafsir at which we aim is to understand the Book as a path which guides people to that which will give them happiness in this life and the next, for this is its highest aim, and all other endeavours are subordinate to this or a means of attaining it. ${ }^{25}$ Rida brought forth critical framework of exegesis advocating rational and independent method of commentary, and profoundly expounded Abduh's modern and scientific principle in explicating the text, although he differed slightly from the Imam in certain aspects of tafsir, as mentioned by Harun Nasution "Rida, as various authors have rightly observed, does not always follow 'Abduh's views" ${ }^{26}$. This was also suggested by Abdullah Mahmud Shihata in his study of al-Manar, "Abduh's contribution was in drawing the general idea of a chapter and the issues with which it deals and the principles and the realities it contains, and that it was carried on by Rida." 27

In furthering his argument, Rida consistently emphasized the primacy of reason and conscious intellect to understand the text, inspiring critical and independent views, that broke the ground for ijtibad , as substantially advocated by Abduh in his lecture, "I do not read other books when I teach, but sometimes I refer to exegetical books if there are strange structures or strange sentences". ${ }^{28}$ Abduh's principal aim

\footnotetext{
22 Iftitah Jafar, "Modern Qur'anic Exegesis: A Comparative Study of the Methods of Muhammad "Abduh and Muhammad Rashid Rida" (M.A. Thesis, Institute of Islamic Studies, McGill University, 1998), 31.

23 Jane Dammen McAuliffe, Qur'anic Christians: An Analysis of Classical and Modern Exegesis (Cambridge: Cambridge University Press, 1991), 79, Iftitah Jafar, 1998, 32, ibid.

${ }^{24}$ Rashid Rida, Tafsir al-Manar (Beirut: Dar al-Kutub al-'Ilmiyyah, 1999), 1/17, alDhahabi, Muhammad Husayn, Al-Tafsir wa'l-Mufassirun (Cairo: Maktabah Wahbah, 1989), $2 / 552$.

${ }^{25}$ Iftitah Jafar, 1998, 37, op.cit.

${ }^{26}$ Harun Nasution, "The Place of Reason in 'Abduh's Theology: Its Impact on his Theological System and Views" (Ph.D Thesis, Institute of Islamic Studies, McGill University, 1968), 8.

${ }^{27}$ Harun Nasution, ibid., Abdullah Mahmud Shahatah, Manhaj al-Imam Muhammad 'Abduh fi Tafsir al-Qur'an al-Karim (Cairo: Matba'ah Jami'ah al-Qahirah, 1984).

${ }^{28}$ Iftitah Jafar, 1998, 37, op.cit.
} 
was to derive the lesson from the Qur'an and its ethical significance, as claimed by J.M.S. Baljon in his Modern Muslim Koran Interpretation "in my opinion the most distinguishing feature of 'Abduh's Koran comments is his apparent desire to give moral lessons whenever the text affords an opportunity." ${ }^{29}$ "He insisted on the need to simplify the tafsir, contending that "modern traditional exegesis offers little more than an elaborate repetition of the various opinions of the classical exegetes, and that these essentially dated interpretations tend to alienate people from the aims of revelation." 30

In the subsequent edition of Tafsir, Rida provided greater background to the work, with expanded commentary, and robust discussion on technical ideas, concentrating on significant foundation of scientific and independent spirit, as emphasized in the introduction: "This is the only interpretation that has brought forth genuine and authentic report with clear and rational thought, certifying which is branch and which is fundamental, solving various problems in religion, denied the arguments of the materialists and atheists, advocated the legitimate proofs of Islam, describes its ideal in realizing the general welfare (maslabab) of mankind and explains the wisdom in the application of legal rule and the divine provision encountered in human life. This interpretation also explains that the Qur'an is the universal guidance or instructions from God to all mankind in every time and place, as the irrefutable proof of God and conclusive evidence of immense charmed and immortal truth. This book also describes the conformability between instructions of the Qur'an and the needs of the Muslims, whether they are living at present in a state of collapsed and inferior, because most of them have thrown these guidance, or they live in the past in a state of thriving and prosperous, because they always adhere to it, and that is the path that leads them to happiness in this world and in the hereafter. This interpretation conclusively maintained that its description can be understood easily and avoiding the use of words heaped with technical terms of science and art. As such the interpretation can be used as guidance by the layman, and equally indispensable for the adept. That is the way in which

\footnotetext{
${ }^{29}$ J.M.S. Baljon, Modern Muslim Koran Interpretation (1880-1960) (Leiden: E.J. Brill, 1968), 2 .

${ }^{30}$ Rida, 1999, op.cit.

126 Ahmad Nabil Amir - The Influence Of Abduh's
} 
the philosopher, al-Ustadh, al-Imam al-Shaykh Muhammad 'Abduh followed in his lecture on this commentary." ${ }^{31}$

After the death of Abduh, the work substantially expanded by Rida with greater emphasized on traditional doctrines, and crucial focus on moderate views. He occasionally refers to many great classical and modern commentaries ranging from al-Tabari's Jami al-Bayan Fi Ta'wil Ay al-Qur'an to Al-Suyuti and al-Mahalli's Tafsir al-Jalalayn to al-Alusi's (18021854) Rub al-Ma'ani fi Tafsir al-Qur'an wa Sab' al-Mathani. He outlined critical foundation for reform and inspired modern and social interpretation, as he maintains: "after teacher's death, I use different interpretation unlike the method which have been used by teacher these methods are enlarging explanations with authentic traditions, certifying the words, sentences, and the problems that have caused disagreement among scholars. He amplified the evidence and strengthen its arguments through quoting from various passages and sura, reinforce the argument which deal with problems that need timely solution in current situation of Muslims based on guidance provided by their religion, strengthen their arguments in confronting their enemies, both from the pagans and heretics, or solving the problems in a way that can be reassuring and soothing to mind." ${ }^{32}$

His commentary avoids the meticulous detail lavished by classical tafsir on the examination of art, language and literary, and was absolutely free and unbounded from past authorities.

According to A. Athaillah, Rida's exegetical work not only interpret the verses of the Qur'an, but also constitute the vehicles and channel of reform initiated by Abduh, "through his commentary, he associate the teaching of the Qur'an with people's life, affirming the universal and eternal character of the religion of Islam, which is always in conformity with the needs of people in all times and places. He aligned the teaching of the Qur'an with the development of science at his time." ${ }^{33}$ This profound contributions to publicize 'Abduh's modern ideal, and propagate his principle doctrines was instrumental in spreading his dynamic and profound commentary, as mentioned by Abdullah Mahmud Shahatah that "If Rida never published Abduh's ideas of reform, we will

\footnotetext{
${ }^{31}$ Rida, 1947, 9, ibid.

32 Ibid, 1947, 16.

33 A. Athaillah, Rasyid Ridha: Konsep Teologi Rasional dalam Tafsir al-Manar Jakarta: Penerbit Erlangga, 2006), 2.
} 
not be able to recognize this brilliant ideas, especially in the field of Qur'anic exegesis". ${ }^{34}$

\section{The Tarikh}

Kitab Tarikh al-Ustadh al-Imam Mubammad Abduh was the principal work of Rida that documented Abduh's intellectual legacy and major source on his life and career in Egypt. It was extended from Rida's early brief biography, Al-Mulakhkhas fi Sirat al-Ustadh al-Imam released in alManar's journal, (vol. viii, 1905). The important of this work was described by Charles C. Adams: "the only biography of considerable length concerning him was that from the pen of Muhammad Rashid Rida which was printed in vol. viii (1905) of al-Manar, the monthly journal of the "Abduh party". ${ }^{35}$

The Tarikh was published in three principal volumes that continue to become the most definite, undisputed and standard references concerning Abduh's life, "with its more than one thousand pages, as the last and fullest source-book for a biography of Muhammad "Abduh". ${ }^{36}$ The volume "contains a wealth of incident and detail concerning events and persons; throws most interesting and valuable sidelights on modern Egyptian history; reveals inner details of the various intrigues, political or otherwise, in which 'Abduh was involved, sometimes as author but more frequently as victim." 37

The publication of this biography, was unmatched in its detail and comprehensive account and had surpassed the previous works on Abduh by Goldziher, Horten, Hartmann, H.A.R. Gibb, Mustafa 'Abd al-Raziq and M. Bernard Michel, as affirmed by Charles C. Adams "this long awaited volume by the chief disciple of "Abduh, who has carried on his tradition, must remain the principal source of information regarding the life and work of the great Egyptian reformer." ${ }^{38}$

Volume I contained full biography, which appeared in the latter months of $1931^{39}$ of al-Manar and covered about 1134 pages. The second volume contained Abduh's major articles and briefer works, collected from various sources, and published in 1908. Volume III contain biographical and eulogistic accounts which appeared at the time

\footnotetext{
34 Abdullah Mahmud Shahatah, 1984, 209-10, op.cit.

35 Charles C. Adams, 1933, vii, op.cit.

36 Ibid.

${ }^{37}$ Ibid.

${ }^{38}$ Ibid, 1933, vi-vii.

${ }^{39}$ Ibid, 1933, vi.

128 Ahmad Nabil Amir - The Influence Of Abduh's
} 
of his death, letters and telegrams of condolence, published on the fifth anniversary of his death, in $1910 .{ }^{40}$

The Tarikh represents monumental contributions of Rida to undertake a comprehensive work in constructing extensive account of Abduh and republished the bulks of his works and worldviews, as depicted by Charles C. Adams in his Islam and Modernism in Egypt. "as the leading pupil of Muhammad 'Abduh during the latter's lifetime, and, since his death, his biographer, editor of his works, and the one who has principally carried on his tradition and interpreted his doctrines, his name cannot be mentioned otherwise than frequently in any study of the movement inaugurated by Muhammad Abduh." ${ }^{41}$ His initiative to construct a comprehensive and detail biography of Abduh and extensively published his works and publicize his ideals was acclaimed widely, as "the man who has been perpetuating Abduh's influence for the quarter of a century since his death." ${ }^{42}$

Rida's far-reaching contributions to publicizes Abduh's views, was greatly hailed by Abduh himself, who strongly defended him and denounced the disparaging controversy that undermine his character and condemned those who spread slander and assailed negative views on him, "No one of you is able to take over his duties. Bring others like him to me, and I will leave him. He never told me what you have say it. Now I reiterate to you that God has sent him to me to prolong my life and extend my age. Many things in my mind that I want to write and explain to people, but I can't do that, because of various matters that bustle me. Since then, only he can do it precisely like what I want. If I mention a topic to him to write about in al-Manar, he then wrote it as I wanted to. If I declare something to him in general, he then outlining and explaining the way I desire to. He who finished what I started and enunciated what I indicated and affirmed. In my visit to Tunisia and Europe, I could see the results of his labors and influence of the magazine of al-Manar that he ran. This had never been predicted before. In fact, he has also managed to collect a number of groups of students, and comrades who became my supporters." 43

Rida's instrumental role in advocating Abduh's principle was highly crucial, and important, that "if it were not for al-Manar most of

\footnotetext{
${ }^{40}$ B. Michel, Moustapha Abdel Razik, Introduction sur la vie et les idees du Cheikh Mohammed Abdou, introduction to Rissalat al Tawhid: expose de la religion musulmane (Paris: P. Geuthner, 1925), C.C. Adams, 1933, vii, op.cit.

${ }^{41}$ C.C. Adams, 1933, 177.

42 Ibid.

${ }^{43}$ Rida, Rashid, Tarikh al-Ustadh al-Imam ash-Shaykh Muhammad 'Abduh (Cairo: Matba'ah al-Manar, 1931), 1018.
} 
'Abduh's thoughts and wisdom would have been lost, and his reforms and history unknown." ${ }^{44}$ This exceptional and highly important contributions in constructing Abduh's extensive biography and history in al-Manar was certainly unprecedented as proclaimed by Mustafa Abdurraziq "say if Abduh was the leader in religion, Rida is his comrade the interpreter of his school and perfecter of his ideal, the editor of alManar's magazine had exerted all his ability and had undertook various studies and discussions on matters of religion and jurisprudence. His work has brought great influence to the students of the religious sciences and mainstream Islamic studies across the world." ${ }^{45}$

\section{Al-Manar}

The history of modern Islamic reform in Egypt was much connected to the Pan Islamic ideal propagated by al-Manar's magazine, which was initiated by Muhammad Abduh and Rashid Rida in 1898. AlManar was the continuation of al-Afghani and Abduh's political journal, al-Urwa al-Wuthqa founded in Paris in 1884 that echoed the same political aspiration of Pan Islamic views and anti-British sentiments. According to Kosugi, Al-Urwa al-Wuthqa was "the first journal calling for the revival of Islam, or that of the Islamic umma and its civilization...it gave a serious warning of the dangers of Western colonialism, and called for a reform of the umma and exercise of ijtihad (independent reasoning to find Islamic legal rules) to face the challenges of the time. Among the younger generation who received the message of this pioneering journal, was the young Muhammad Rashid Rida in Syria." 46

Rida was inspired by this pioneering journal (al-Urwa al-Wuthqa) that gazette instructive articles calling for radical reform. He discovered the journal from his father's papers which brought tremendous impact in his spiritual consciousness and marked the most defining and momentous event in his life that encouraged him to undertake reform: "I found a copy of al-Urwa al-Wuthqa among my father's papers. When I read its articles on the call to pan-Islamism, the return of glory, power and prestige of Islam, the recovery of what it used to possess, and the liberation of its peoples from foreign domination, I was so impressed that I entered into a new phase of my life. And I became very fond of

\footnotetext{
44 Anwar al-Jundi, Tarajim al-A 'lam al-Mu'asirin fi al-'Alam al-Islami (Cairo: Maktabah alAnglo, 1977), 77, quoted in Kosugi, 2006, 13, op.cit.

45 A. Athaillah, Rasyid Ridha: Konsep Teologi Rasional dalam Tafsir al-Manar (Jakarta: Penerbit Erlangga, 2006), 2.

${ }^{46}$ Kosugi Yasushi, 2006, 8, op.cit.
} 
the methodology of these articles to make and prove its arguments on topics with verses from the Qur'an, and of its tafsir (exegesis) which none of mufassirs (exegetes) have written. The most important points in which al-Urwa al-Wuthqa distinguished itself were: (1) Allah's rules in His creation and the order of human society, and the reasons for the rise and fall of nations as well as their strength and weakness; (2) clarification that Islam is a religion of sovereignty and power, combining the happiness of this world and that of the hereafter, while implying that it is a religion both spiritual and social, civil and military, and that its military power is for the sake of protection of the just law, general guidance and prestige of the community, and not for the sake of imposition of the religion by force; and (3) for Muslims there are no nationalities except their religion, so they are brothers whose bloodline must not separate them, nor their languages nor their governments." 47

In 1897, Rida decided to move to Cairo to publish al-Manar with Muhammad Abduh after his initial plan to meet Afghani did not materialized since Afghani continued to stay in Istanbul until his death in 1897. He had initially written to Afghani in 1893 expressing his admiration and anticipation to join his circle in Constantinople. Rida greatly admired al-Afghani and revered him as "The Awakener of the East" (Muqiz al-Sharq) and was remembered as "Adorer of al-Afghani" by his colleagues. In 1897 he traveled to Cairo with Farah Antun (18741922), the founder of the secularist journal Al-Jami' $a$ and plunge into remarkable career in journalism. Relating this momentous journey, he stated: "when he [al-Afghani] passed away, my hope was heightened to get in touch with his viceroy Shaykh Muhammad 'Abduh to acquire his knowledge and opinions on Islamic reform. I waited until an opportunity appeared in the month of Rajab in 1315 [1897], and that was immediately after I completed my study in Tripoli, acquiring an 'alim status, permission to teach independently, from my mentors. Then I immigrated to Egypt, and established al-Manar for call to reform." ${ }^{48}$

The printing machines were invented in Egypt in this period, which greatly impacted the literal renaissance of the masses. It marked the critical milestone in the rise of newspapers and magazines in modern Egypt, and it was timely for Al-Manar to surface following this development, to propagate and publicize its ideas, "everywhere the

${ }^{47}$ Rashid Rida, Tafsir al-Manar (Cairo: Dar al-Hay'a al-Misriyya al-'Amma li-l-Kitab, 1971), 11, Albert Hourani, Arabic Thought in the Liberal Age 1798-1939 (London: Oxford University Press, 1967), 226.

${ }^{48}$ Rashid Rida, 1972, 12, op.cit. 
increased use of the printing press for publishing religious texts challenged the 'ulama's role as guardians and transmitters of knowledge...the reformers of Islamic law were aware of the opportunities that the print media opened up. They skillfully used periodicals and pamphlets to disseminate their opinions to a wide audience." 49

Al-Manar was first released in 1898, as "a monthly magazine that researches the philosophy of religion and the affairs of society and civilization". ${ }^{50}$ It derived the title from the hadith of the Prophet (saw) that "there were in Islam landmarks and a lighthouse, like a lighthouse of the path." The journal was initially published eight-page weekly, and on monthly based commencing from the second year of issue. 1,500 copies were printed in the first issues and sent to neighboring province in Egypt and Syria. After the Ottoman authorities banned its circulation in Syria, its copies were reduced to 1,000 . But, in few years later, its subscribers escalated to approximately 3,000, and "by the twelfth year (1909), remaining copies of volume I were selling for four times the original price; a second printing was therefore made, in the form which had been followed after the first year." 51

Al-Manar strongly proclaimed the ideas of reform advocated by Abduh. It had exerted great influenced in the Islamic world and has became "the mouthpiece for the propagation of 'Abduh's doctrines and the accomplishment of his reforms." " 2 It "has been the organ through which his ['Abduh's] views have been given the largest publicity." ${ }^{3} \mathrm{Al}$ Manar undertakes crucial role in the reform struggle, contributing to "proposed the cures for the illness of the umma in a general form, then with details and proofs." ${ }^{54}$ It aspired to restore the dynamic role of the umma and to reclaim their important and significance position in world civilization, as asserted by Kosugi "the journal of al-Manar was meant to reaffirm the validity of Islam as a religion in the contemporary world, of Islam as a civilization in the modern context." ${ }^{55}$ It strive to awaken the umma from their deep stagnation and long slumber, as decisively pronounced in the introduction: "This is a voice calling in a clear Arabic

\footnotetext{
${ }^{49}$ Felicitas Opwis, Changes in Modern Islamic Legal Theory: Reform or Reformation? In Michaelle Browers and Charles Kurzman, (eds.), An Islamic Reformation? (pp. 28-53) (Lanham: Lexington Books, 2004), 34-5, Kosugi, 2006, 9, op.cit.

${ }^{50}$ Rashid Rida, Majallat al-Manar, vol. I, (2nd ed.) (Cairo: al-Manar, 1909).

${ }^{51}$ C.C. Adams, 1933, 180-81, op.cit.

52 Ibid, 1933, 178.

53 Ibid, 1933, 205.

${ }^{54}$ Rida, 1909, 8, op.cit., quoted in Kosugi, 2006, 10, op.cit..

${ }^{55}$ Kosugi, 2006, 17, ibid.
} 
tongue, and an appeal to the truth reaching the ear of a speaker of the dad letter [an Arab] and the ears of all Easterners, calling from a close place [Egypt, located between the West and the East] which both the Easterner and the Westerner can hear, and it spreads out so that the Turks and the Persians also receive it. It says: "Oh, the sleeping Easterner who enjoys sweet dreams, wake up, wake up! Your sleep has exceeded the limit of rest." ${ }^{56}$

Al-Manar continued to publish for three decades until 1935, and its reputation was broadly proclaimed and "eventually gained a wide circulation from Morocco to Java," 57 as remarked by C.C. Berg " $A$ Manar did not shine...for Egyptians alone. It illuminated the Arabs at home and abroad, the Moslems of the Malay Archipelago who studied at al-Azhar University or in Mecca, and the solitary Indonesian who had kept his old relations with the heart of the Moslem world after having returned to his border country of the Dar al-Islam... And all these people now saw Islam in a new light... Those who had caught up and preserved the light of the Manar in Egypt, became lesser "manars" for their environments, once back in Indonesia." 58

The contributions of al-Manar to proclaim Abduh's progressive ideas and reviving his salafis doctrines, was acclaimed by former rector of al-Azhar, and disciple of Abduh, al-Ustadh al-Shaykh Mustafa alMaraghi (1881-1945), in his speech on the occasion of commemorating his funeral: "al-Sayyid Rashid triumphed and his supporters and disciples became many, while there were once few supporters and disciples, and within academic circles there were found those who carry his principles and follow his path, and among the public those whose eyes were opened to light, and clouds of ignorance and falsehood were wiped out of their hearts. He didn't have any new principle in Islam, that could be justified as a school of his own, but his principle was the principle of the entire 'ulama' of the salaf, that is, to return in judgment to God and His messenger (saw) by executing [the following Qur'anic order in the verse of] "and if you have a dispute concerning any matter, refer it to Allah and the messenger (saw)" [Qur'an 4: 59], and his principle was also that of the 'ulama' of the salaf in choosing rules appropriate for the time and beneficial for nations in issues of ijtihad [where independent judgment should be exercised], and his principle was that of the 'ulama' of the salaf

\footnotetext{
${ }^{56}$ Rida, 1909, 9, op.cit.

57 H.A.R. Gibb, Mohammedanism: An Historical Survey, 2 $2^{\text {nd }}$ ed. (London: Oxford University Press, 1964), 178.

${ }^{58}$ C.C. Berg, "Indonesia", in H.A.R. Gibb, (ed.), Whither Islam? A Survey of Modern Movements in the Moslem World (New York: AMS Press, 1973), 268-69.
} 
in everything related to Divine attributes and the issues related to the last day, so he was a salafi sunni man who disliked taqlid (uncritical emulation) and propagated ijtihad, seeing it [ijtihad] an obligation upon himself and upon everyone capable." ${ }^{59}$

\section{Educational Reform}

Abduh largely concentrated his reformist work on education, and his far-reaching achievements had seriously impacted Rida in advocating educational reform extensively in al-Manar, as definitely explained by Kosugi: "In doing so (maintaining the publication of al-Manar), Rida depended upon al-Afghani and 'Abduh to a great extent, especially at the beginning. This is partly because he had faith in their thought and believed that their cause was not only correct but also beneficial to all members of the Islamic world. Their authority and credibility were assets to him." 60

Abduh has exerted his career and putting great effort to improve and transform educational landscape in Egypt, focusing his effort to uplift education and religious consciousness of the umma, as observed by Osman Amin: "the educative and ethical aspects of Abduh's modernism explain the pervasive influence this Egyptian reformer had had in some parts of the Muslim world." ${ }^{61}$

Al-Manar echoed this idea of reform by advancing significant worldview advocated by Abduh that fundamentally proclaimed religious reform (islab), spiritual improvement, and inspired ethical transformation, and it continue to influence the transformation and development of education in the Muslim world, and the proliferation of progressive Islam by "adopting the science and technology of the West." ${ }^{62}$ According to Kosugi "Al-Manar is a treasure of historical sources for the Islamic areas of its days." ${ }^{63}$

The struggle for reform had inspired progressive and scientific achievement and advanced modern worldview. Abduh's essential effort was concentrated to improve the condition of the umma and its educational pursuit, as described by Ahmad Bazli Shafie in his critical work on Abduh's significant philosophy and framework of education, The Educational Philosophy of al-Shaykh Muhammad Abduh, "education was

\footnotetext{
${ }^{59}$ Kosugi, 2006, 11, op.cit.

${ }^{60}$ Ibid, 2006, 12.

${ }^{61}$ Osman Amin, "The Modernist Movement in Egypt" in Islam and the West: Proceedings of the Harvard Summer School Conference on the Middle East (July 25-27, 1995), 167-8.

${ }^{62}$ Hunt Janin, The Pursuit of Learning in the Islamic World, 610-2003 (North Carolina: McFarland, 2005), 145.

${ }^{63}$ Kosugi, 2006, 7, op.cit.
} 
the most vital means and the key to 'Abduh's efforts to halt the decline of the Muslim world". ${ }^{64} \mathrm{He}$ sought to reassert the dynamic civilization and encourage the excellent pursuit of knowledge, arguing that: "Islam urged Muslims to seek knowledge and to spread it because the Prophet of Islam (saw) had asked Muslims to seek knowledge even in China. Islam emphasized the importance of knowledge and within two centuries from the emergence of Islam "the Muslims were already excelling in all the branches of human knowledge." 65

This fundamental aspiration to inspired knowledge and scientific endeavor, was greatly expounded in al-Manar, that marked Rida's enduring contributions to articulate and conceptualize Abduh's fundamental views and main idealism on educational reform, and the primacy of reason, as he categorically argued: "Islam persistently encourages man to use reason and to study created beings through the laws and natures that govern them in order to know their creator, God."

\section{Ijtihad (Independent Judgment)}

The principle of ijtihad was the foremost ideals rigorously advocated by Abduh in his struggle for reform and renewal. He strongly rejected the passive and uncritical adherent to past authorities (taqlid) and emphasized the application of ijtihad (independent reasoning) arguing that, "Islam attributed folly and levity to those who accept blindly the words of their predecessors. And it call attention to the fact, that precedence in point of time is not one of the signs of knowledge, nor a mark of superiority of intellect or intelligence; but that the preceding generations and the later are on an equality so far as critical acumen and natural abilities are concerned." ${ }^{67} \mathrm{He}$ encourages the critical use of reason and defended it emphatically, claiming that: "Islam is preeminently a religion of reason" ${ }^{68}$ and that "Islam and reason were totally compatible if Islam was properly understood."

Abduh insisted on the important of science and the power of intellect: "in the search for truth, Islam prescribes reason, condemns blind imitation, and blames those who attach themselves without

\footnotetext{
${ }^{64}$ Ahmad Bazli Shafie, The Educational Philosophy of al-Shaykh Muhammad Abduh (Kuala Lumpur: International Institute of Islamic Thought and Civilization, 2004), vii.

${ }^{65}$ Osman Amin, 1995, 172, op.cit., C.C. Adams, 1933, 128, op.cit.

${ }^{66}$ C.C. Adams, 1933, 128, ibid.

${ }^{67}$ C.C. Adams, 1933, 132, ibid, Ibrahim Abu Bakar, "Islamic Modernism in Malaya as Reflected in Hadi's Thought" (Ph.D. Thesis, Institute of Islamic Studies, McGill University, Montreal, 1992), 58.

68 Adams, 1933, 128, ibid.
} 
discernment to the habits and opinions of their forefathers." ${ }^{69} \mathrm{He}$ maintained that the later generations had more explicit ground and profound reason to exercise ijtihad, "the later generations of Muslims have better knowledge than the earlier generations because the latter have the capacity to acquire knowledge of past circumstances, to reflect upon them and to use them for their benefit in the world in the light of present knowledge and circumstances." ${ }^{70}$ In the struggle for reform and renewal, he encouraged the pursuit of rational and critical judgment, and strongly denounced the passivity and stagnancy of the blinkered conservatives, as pointed out by Sayyid Qutb: "Abduh grew up in a strict society where rational inquiry was discouraged, among scholars who regularly neglected the role of reason in understanding God's doctrines." 71

Rida explicitly defended and reinforced Abduh's position in condemning taqlid (blind imitation), and denounce the shackles of uncritical emulations and obedience to past authorities (taqlid) as illustrated by Kosugi "his [Rida] major contribution was that he disseminated these ideas [ijtihad, anti-taqlid] widely in the Islamic world through the most enduring and consistent medium in the modern era, the journal of al-Manar". ${ }^{72}$ In Rida's opinion, taqlid had damaging consequences for the umma that conclusively led to factionalism, "what is harmful is fragmentation of Muslims into sects and parties, while each of them requires its members to follow a scholar whom they call an imam, and they follow him in every word and opinion, and assemble themselves against the followers of another scholar, leading finally to the negligence of the Book [Qur'an] and the sunna [prophetic (saw) tradition $]^{73}$

In explicating the fundamental influence of Abduh and the important and significant basis of ijtibad, Rida proclaimed the critical impact of Abduh that inspired him to carry on his tradition in his advocacy of ijtibad: "I have similarities with the teachers in the use of freedom of thought and argument, both in religious and scientific problem. It is already an imperative for me since the first day I became his disciple. I have studying a lot of science, philosophy and many subjects from teacher, but I never blindly emulated him. In many ways I

\footnotetext{
${ }^{69}$ Osman Amin, 1953, 172, op.cit.

${ }^{70}$ C.C. Adams, 1933: 132, op.cit.

71 Sayid Qutb, Khasa'is al-Tasawnur al-Islami wa Muqawnimatub (Beirut: Dar al-Shuruq, 1980), 19.

${ }^{72}$ Kosugi, 2006, 11, op.cit.

${ }^{73}$ Rashid Rida, "Muhawarat al-Muslih wa al-Muqallid", in Al-Manar 4, 1901: 209-210, 362-63, quoted in Kosugi, 2006, 15, op.cit.
} 
agreed with the teacher, but in some ways I disagree, in fact I rejected the argument with my own proof. We have similarities in principle, goal, motivation, and intention." 74

Rida idealized the spirit of reform and independent judgment advocated by Abduh through his fatwas in al-Manar, that resonated Abduh's impressive ruling and his remarkable legacy in the twentieth century, as observed by Shaykh Yusuf al-Qardawi in illustrating the influence of al-Manar's magazine in the Islamic world: "after that [the periods of traditional fatwas], fatwas of al-'allama al-mujaddid [great renewer scholar] al-Sayyid Muhammad Rashid Rida had become famous, which were published in his noble Islamic journal, al-Manar, a journal which continued for thirty five years. Each issue always had one or more fatwas, answering questions from the readers of the journal in the Islamic world. For this reason, the questions and answers did not represent any particular locality, but addressed problems the entire Islamic umma and Muslims in all corners of the earth were facing...these fatwas had many features. First, they treat modern issues and actual problems which peoples face and suffer and need to know the answers of Islamic law, or at least, contemporary Islamic ijtihad (judgment, reasoning) on them. Second, they are written with a spirit of intellectual independence, with freedom from bonds of sectarianism, imitation, and narrow-minded insistence on a particular view. He did not refer except to the Book [Qur'an], Sunna, and the foundations of the Islamic law...third, they carry the spirit of reform and the invitation to the balanced comprehensive Islam." ${ }^{75}$

Rida also discussed the significance and crucial foundation of ijtihad in his work Mubawarat al-Muslih wa al-Muqallid (The Dialogues between the Reformer and the Imitator/Traditionalist), that was published in al-Manar from vol. 3, no. 28 (December 1900) to vol. 4, no. 22 (February 1902), where he painstakingly emphasis the crucial need of ijtihad: "the basic fundamentals of Islam are proper creed, ethics, control of one's own soul, and worshipping Allah in an appropriate manner, and general principles for social relations such as protection of life, honor and property. All these principles were established in the time of the Prophet (saw)... as for the details of social relations, after the foundations are laid such as justice of rulings, equality of rights, prohibition of transgression, deception, and treason, and hadd punishments for some crimes, and after

\footnotetext{
${ }^{74}$ Rashid Rida, Tarikh al-Ustadh al-Imam ash-Shaykh Muhammad 'Abduh (Cairo: Matba'ah al-Manar, 1931), 1019.

${ }^{75}$ Al-Qaradawi, Al-Fatwa bayna al-Indibat wa al-Tashayyu' (3rd ed.) (Cairo: Dar al-Sahwa, 1992), 17-18.
} 
the principle of shura (mutual consensus) is established, the details are entrusted to those with authority among the scholars and rulers, who ought to be possessors of knowledge and justice, deciding what is best for the umma according to [conditions of] the time." 76

\section{Islamic Proliferation (Da'wah)}

The intensity of da'wah, and its advocacy in al-Manar, was highly inspired and influenced by Abduh's worldview that concentrated to empower umma and advocate religious ideal based on Qur'anic weltanschauung. In their effort to proclaim and idealized the movement, Abduh and Rida had founded Jam 'iyyah al-Irshad [The Benevolent Society] and Madrasa al-Da'wa wa al-Irshad [Propagation and Guidance], an elite school that was established in Egypt in $1912^{77}$ which undertake important task to recruit young cadre and extend Islamic preaching and striving to improve the condition of the ummah.

The crucial role of al-Manar in Islamic propagation and da'wah and its struggle to mobilize the new force of reform was strengthened by the formation of al-Manar party or "moderate party of Islamic reform" (bizb al-islah al-Islami al-mu'tadi) that convincingly advanced al-Manar's aspiration. Its movement was stretched into broader Islamic world. The struggle and advocacy of Islamic da'wah was significantly shouldered by younger Egyptian modernist and preachers, such as Tantawi Jawhari, Muhammad Farid Wajdi, Qasim Amin; and scholars in Tunis and Maghrib such as 'Abd al-Aziz al-Thaalibi, Muhammad ibn Nahil, Tahir b. Ashur, and Ben Badis and their counterpart in Malay archipelago, such as Syed Shaykh al-Hadi, Syeikh Muhammad Tahir Jalaluddin al-Falaki alAzhari, Shaykh Abdul Karim Amrullah (Haji Rasul) and Shaykh Abdul Malik bin Abdul Karim Amrullah that contributed to strengthened and extended the struggle of al-Manar. They undertake significant part of religious reform and further idealized the works of Abduh and Rida championing and defending their modernist and salafis ideals, as remarked by Hunt Janin in his book, The Pursuit of Learning in the Islamic World, 610-2003 "his [Abduh] teachings inspired the Salafiya (a reformist movement designed to purify Islam through a blend of traditional, modernist, and nationalistic thought) in Egypt, the Arab Middle East, and North Africa." ${ }^{78}$ And that "the understanding of Rashid [Rida]

\footnotetext{
${ }^{76}$ Rida, 1901: 209-10, quoted in Kosugi, 2006: 15, op.cit.

${ }^{77}$ Kurzman, Charles, ed., Modernist Islam 1840-1940 (Oxford: Oxford University Press, 2002), 89.

${ }^{78}$ Hunt Janin, 2005, 142, op.cit.
}

138 Ahmad Nabil Amir - The Influence Of Abduh's 
Efendi and Shaykh Muhammad 'Abduh of the religion of Islam helps progress and benefits the state" 79

In the Malay-Indonesian world, the spread of Islamic reform and da'wah as advocated by Abduh was actively propagated, as illustrated by H.A.R. Gibb, "persons who accepted the principle of al-Manar in Egypt, upon returning to their own countries, formed small groups of al-Manar supporters (al-Manarat)." ${ }^{80}$ Part of Tafsir al-Manar was translated by Syed Shaykh al-Hadi in 1908 and published in al-Imam's magazine, which began with sura al-Fatihah (no. 3, vol. 3, 29 August 1908) and was broadly proclaimed in Malaya, Singapore and Indonesia. Al-Hadi also published the translation of Tafsir Juг 'Amma in Al-Ikhwan's journal and translated Abduh's Tafsir al-Fatihah, in 1928, that constituted about 127 pages. ${ }^{81}$

\section{Islamic Reform (Tajdid)}

The significance teaching of Abduh's religious thought was profoundly developed and extended by Rida is his leading periodic alManar. He proclaimed and advocated Abduh's dynamic aspiration in the Muslim world, reinforced and reasserted his reform ideas: "The UstadhImam (teacher-imam) ['Abduh], may God bestow mercy upon him, reached the leadership position in this umma and the level of those in authority in the religious and temporal affairs, and he came quite close to the leadership of the entire umma. But this potential was not realized, because the umma was not formulated in such a manner to make it possible to move on the line which he planned." 82 Rida significantly contributed to advocate and proclaim the ideas of renewal through alManar that effectively gained wide influence in major Arab countries in the Middle East, North Africa, and Southeast Asia. "He was strongly influenced by the reformist ideas of al-Afghani and especially of Abduh. Indeed, Al-Manar, the highly-regarded reformist monthly magazine that Rashid Rida published for 37 years (from 1898 to 1935), was essentially a call for change according to the doctrines of Abduh." ${ }^{83}$

Al-Manar's extensive contributions to spread Abduh's reform ideal was exceptionally instrumental in realizing his modern idealism and principle, as convincingly argued by A. Athaillah in his book Rasyid

\footnotetext{
${ }^{79}$ Kurzman, 2002, 83, op.cit.

80 Osman Amin, 1955, 227, op.cit.

${ }^{81}$ Mustaffa Abdullah et. al, "Sayyid Muhammad Rasyid Rida's Influence on Tafsir Studies in Malaysia" in Middle-East Journal of Scientific Research 12:6 (760-766, 2012), 762.

${ }^{82}$ Rashid Rida, Al-Khilafah, aw al-Imamah al-Uzma (Cairo: al-Manar, 1923), 59-60, quoted in Kosugi Yasushi, 2006, 12, op.cit.

${ }^{83}$ Hunt Janin, 2005, 144, op.cit.
} 
Ridha: Konsep Teologi Rasional dalam Tafsir al-Manar (Rashid Rida's conception of rational theology in Tafsir al-Manar) "in the history of modern Islam Abduh was hailed as the most successful reformist, however, this success can't be realized by his efforts alone, but also the result of the gracious works and contributions of his closest students Sayyid Muhammad Rashid Rida, who unfailingly and untirelessly publicize and disseminate his thoughts throughout the Islamic world in his magazine al-Manar, Tafsir al-Manar, and his other works." ${ }^{84}$

The reform struggle fundamentally aims to reclaim the dynamic role and critical position of the ummah in the modern world. Rida strongly emphasized this aspiration by initiating strategic movement that significantly influence the rise of Islamic modernism in the twentieth century, as depicted by Malcolm Kerr in his definitive work, Islamic Reform: The Political and Legal Theories of Muhammad 'Abduh and Rashid Rida that asserted the contributions of Rida in advocating and establishing liberal political ideal and the principle of freedom in the secular world: "Rashid Rida and others of his school, whatever their intentions may have been, have facilitated the accomplishment of a great undertaking of secular reform in Islamic countries".

The struggle focused fundamentally on the revival of Islamic umma from decades of backwardness and long slumber as remarked by Hunt: "intellectually, Rashid Rida began precisely where al-Afghani and Abduh had begun. He first raised a fundamental question - "Why are Muslim countries so backward?" - and then answered it by tying religious belief directly to secular power and prosperity." 86 Rida advocated the aspiration for reform with systematic change and profound shift in moral precepts and religious outlook, as described by Shakib Arsalan (1869-1946) "the teachings and moral precepts of Islam are such that if they are properly understood and fully obeyed, they will lead to success in this world as well as the next - and to success in all the forms in which the world understands it, [namely] strength, respect, civilization, happiness. If they are not understood and obeyed, weakness, decay, barbarism are the results...it is irrelevant to say that modern civilization rests on technical advance, and that Islamic civilization cannot be revived so long as the Muslims are technically backward; technical skill is potentially universal, and its acquisition depends on certain moral

\footnotetext{
84 A. Athaillah, Rasyid Ridha: Konsep Teologi Rasional dalam Tafsir al-Manar (Jakarta: Penerbit Erlangga, 2006), 1.

${ }^{85}$ Malcolm Kerr, Islamic Reform: The Political and Legal Theories of Muhammad 'Abduh and Rashid Rida (Berkeley, Los Angeles: University of California Press, 1966).

${ }^{86}$ Hunt Janin, 2005, 144, op.cit.
} 
babits and intellectual principles. If Muslims had these, they would easily obtain technical skill; and such habits and principles are in fact contained in Islam." 87

\section{Politics}

Rida's political activism, and his prolific writing on the theory and principle of Islamic politics clearly advocated and accentuated the political ideal projected by Abduh, that fundamentally aim "to adjust Islam to the demands of modern times." ${ }^{88}$ Rida discussed political issues in al-Manar after the death of Abduh in 1905, as Abduh discourages him from discussing politics in this critical period. Rida's political writings were compiled in six volumes by Yusuf Ibish and Yusuf Quzma al-Khuri in Maqalat al-Shaykh Rashid Rida al-Siyasiyya (Beirut: Dar Ibn 'Arabi, 1994), that reflected the great turbulent and heated political climates in the Muslim world.

Rida strongly proclaimed the political aspiration of Abduh, which advocated the compatibility of religion and politics as established in his writing al-Islam wa al-Nasraniyyah ma'a al-Tlm wa'l Madaniyyah (Islam and Christianity in Relation to Science and Civilization), "Muhammad Abduh, with all his emphasis upon the spiritual character of religious exercises, defended the union of the civil and religious authority in Islam, and favoured retention of the essentials of the system of canon law, although with far-reaching reforms". ${ }^{89}$ Abduh's advocacy for the establishment of a full fledge Islamic state, was strongly emphasized by al-Manar as described by Hunt Janin: "he [Rida] was one of the first Muslim intellectuals to call for the establishment of a modernized but fully Islamic state and for a reformed sharia, the body of Islamic sacred law." ${ }^{90}$

Rida profoundly advocated Abduh's political aspiration on the idea of Islamic society and the revival of the institution of Caliphate that undisputedly debunked Sa'ad Zaghlul's nationalist thesis. He profoundly outlined the theoretical ground for the establishment of a modern Islamic state, as he proposed: "[The proposal is]...to leave the issue of the khilafa (Caliphate) to all Islamic peoples, and independent and semiindependent governments among them, and constitute a mixed independent committee or assembly with its headquarters in Istanbul, which will study all reports and proposals from the men of knowledge

\footnotetext{
${ }^{87}$ Ibid, 2005, 145.

88 Ibid, 2005, 143.

${ }^{89}$ C.C. Adams, 1933, 267-8, op.cit.

${ }^{90}$ Hunt Janin, 2005, 144, op.cit.
} 
and judgment on the issue, and this will prepare an Islamic conference... ${ }^{91}$

Al-Manar clearly stressed Abduh's fundamental views on the principle of state and governance and the union of religion and politics as proclaimed in his writing, al-Islam wa al-Nasraniyyah ma'a al-Tlm wa'l Madaniyyah. The essential parts of his book al-Khilafa al- 'Uzma and his political theory "Khilafa of the mujtahid" or governance by the jurists in 1920 s, was clearly inspired by the principle ideas of Abduh, that defended the fundamental principle of Islamic governance. In this respect, Al-Manar had "states explicitly and unequivocally" the imperative of Islamic caliphate and refuted 'Ali 'Abd al-Raziq's thesis in Al-Islam wa Usul al-Hukm (Islam and the Fundamentals of Authority) (1925) and his assault on the institution of Islamic caliphate, as Rida significantly argued: "The assertion that the government and the state should be separated from religion, is one that necessitates the blotting of Islamic authority out of existence, and abrogating entirely the Islamic Shari'ah." 92

The institution of governance, according to Rida, must be founded on the crucial principal of freedom, and democratic rule, and this constitutional ideal was critical to realize the modern aspiration of political Islam and revive the classical foundation of its theoretical ideal, as suggested by Malcolm Kerr in his work: " $[\mathrm{H}]$ is revival of the classical theory of the Caliphate serves to remind us that the classical theory itself had not been a program for action but a hyperbolical, almost allegorical, rationalization...Rida's constitutional theory, despite his intentions, does not represent a serious program but a statement of ideals." ${ }^{93}$

The political ideal advocated by Rida was also much influenced from the writings of great Muslim jurists such as al-Mawardi (975-1058), Abu Ya'la al-Farra' (990-1065) and Shihab al-Din Ahmad al-Qalqashandi in their works on the foundation of governance that covered the theory of Islamic Caliphate. This impact was portrayed in his comprehensive expositions on the theory of Caliphate in his al-Khalifa, aw al-Imama alUzma fi al-Islam (Caliphate, or the Supreme Leadership in Islam) which was "presented to the courageous Turkish people and the reform party in Arab and Indian countries and the rest of Islamic People." ${ }^{94}$ The arguments presented give some impression that "Rida thinks the

\footnotetext{
${ }^{91}$ Kosugi, 2006, 23, op.cit.

${ }^{92}$ C.C. Adams, 1933:, 267-8, op.cit.

${ }^{93}$ Malcolm Kerr, Islamic Reform: The Political and Legal Theories of Muhammad 'Abduh and Rashid Rida (Berkeley, Los Angeles: University of California Press, 1966), 220.

${ }^{94}$ Rashid Rida, Al-Khilafah, aw al-Imamah al-Uzma (Cairo: al-Manar, 1923).
} 
traditional system of government still the best" as argued by Emile Tyan, commenting on Henri Laoust's translation of Rida's Khalifa al-'Uzma, entitled Le califat dans la doctrine de Rasid Rida "all the personal efforts of this author, animated by a very intense religious and apologetic spirit led him to propose certain adaptations in order to make possible the restoration of the Caliphate in modern Muslim states." 95

\section{Islamic Rationality}

Rida's rational and progressive views, was strikingly influenced from Abduh's groundbreaking work, Risalat al-Tawhid (The Theology of Unity) which was published in 1897. It illustrated his philosophical ideal and critical and rational framework which was influenced from the

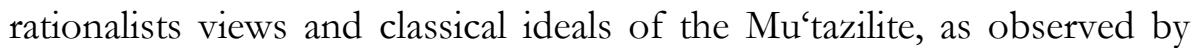
Stewart: "by using the expression the Divine Unity (tawbid) in the title of

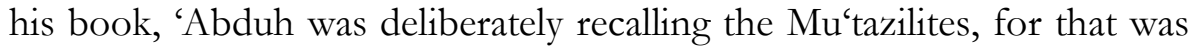
the term that they used to sum up their doctrine. It is clear that he was in fact a latter-day Mu'tazilite, for in the first edition of his Epistle he stated that the Koran is created and not eternal. He was obliged to remove this statement from the later editions, but there seems to be no doubt that his view did not change. He also shared the Mu'tazilite view on such matters as free will and the role of reason in religion" ${ }^{96}$ Abduh's principal position and worldview that supported Mu'tazilite doctrines was further emphasized by Sulayman Dunya, a scholar from al-Azhar, in his comprehensive edition of Abduh's Hashiyah (commentary) of the Sharh al-Dawwani li al-'Aqa'id al-'Adudiyah (1876), which "ranks him as more radical than the Mu'tazilah in giving greater prominence to reason than to revelation" 97

Risalah al-Tawhid was based on his lecture in 1885 in Madrasah alSultaniyya, Beirut, where he taught in his exiled for three years. It was translated into French by B. Michel and Mustapha 'Abd al-Raziq and in English by Ishak Musa'ad and Kenneth Cragg. This principal work formed the foundation of rational Islam that outlined critical framework of rational theology and the supreme position of reason, as explained by Elma Harder: "Abduh's ideas were met with great enthusiasm, but also by tenacious opposition. They are still a subject of contention today...as questions of modernism and tradition re-emerge in conflict in the

\footnotetext{
${ }^{95}$ Rashid Rida, Tarikh al-Ustadh al-Imam ash-Shaykh Muhammad 'Abdub (Cairo: Matba'ah al-Manar, 1931), 2/130, Badawi, 1978, 66.

${ }^{6}$ P.J. Stewart, Unfolding Islam (London: Garnet Publishing, 1995), 194, Iftitah Jafar, 1998, 26, op.cit.

${ }^{97}$ Harun Nasution, 1968, 4, op.cit.
} 
Muslim world. Although he did not achieve his goals, Muhammad Abduh remains a continuing influence, and his work, Risalat al-Taubid (The Unity of Theology) is the most important statement of his thought." ${ }^{98}$ This work stresses "the need to purge Islam of its superstition, to correct Muslim conceptions of the articles of faith, and eliminate errors that crept into Islam on account of textual misinterpretations." 99

Abduh's rational argument had substantial influence in the views of Rida in his advocacy of the principle of Islamic rationalism, as portrayed by Ryuichi Funatsu, in his significant study on al-Kawakibi and Rida, "rather for him, as for Afghani and 'Abduh, a return to the roots, to the first principles, of Islam represented an affirmation of the values of rationalism and freedom inherent in the faith and imperative for its renewal." ${ }^{100}$ In this regard, Rida, argued, that "when holy texts are ambiguous or appear to contradict each other, men should use reason to decide what course of action is most in accord with the spirit of Islam and will further the interests of the Muslim community as a whole." 101

Rida's profound argument was essentially grounded on rational philosophy advocated by Abduh, who reinforced the principle argument of the Mu'tazilite and their method of reasoning, as pointed out by Abdullah Saeed in his work The Qur'an an Introduction "modernist scholars also argued that accepting the concept of revelation did not clash with the use of reason. Thus, they tried to revive Islam's rationalist philosophical tradition, and some previously discounted ideas of the rationalist mu'tazilis came into vogue again among some modern scholars." ${ }^{102}$ This monumental ideal and effort by the modernist to advocate rational and critical views of Islam was significantly illustrated by P.J. Stewart in his incisive work Unfolding Islam: "like the Mu'tazila [the Mu'tazilis], the majority of the modernists emphasize the high place of reason in their scale of values and try to show the perfect compatibility of true Islam with the findings of a mind free from the scourge of ignorance, prejudice and superstitions. Like the Mu'tazila, the modernists think that Islam upholds the principles of free will (ikhtiyar), as opposed

\footnotetext{
${ }^{98}$ Hunt Janin, 2005: 142, op.cit.

${ }^{99}$ Caesar E. Farah, Islam: Beliefs and Observances (New York: Barron's Educational Series, 1994), 231, Iftitah Jafar, 1998, 25, op.cit.

100 Ryuichi Funatsu, "Al-Kawakibi's Thesis and its Echoes in the Arab World Today", in Harvard Middle Eastern and Islamic Review, 7 (2006), 1-40.

${ }^{101}$ Hunt Janin, 2005, 145, op.cit.

102 Abdullah Saeed, The Qur'an An Introduction (Oxford: Routledge, 2008), 209.
} 
to that predestination (jabr), since it has been obvious to both groups that Muslims first conceive of their capacity to determine their destiny. ${ }^{103}$

Abduh's theological reasoning and rational ideas was also magnified by Rida in Tafsir al-Manar, which according to Goldziher "contain the substance of the theology as propagated by al-Afghani and "Abduh." ${ }^{104}$ In his tafsir, Rida tried to explicate Abduh's rational views in traditional way, as pointed out by Caspar, that "Rida is trying to interpret 'Abduh's ideas in a more traditional sense" 105

Rida's advocacy of rational commentary and his effort to idealized Abduh's fundamental philosophy and struggle in defending reason had great ramification in his method and worldview as presented in Tafsir alManar, as contended by 'Uthman Amin, "while Rida in the beginning of the Tafsir al-Manar, follows 'Abduh closely, he later begins to express his own views in a more and more liberal way and begins to deviate from "Abduh's method." 106 This was depicted in his comment on the questions of anthropomorphism, which manifested his critical principle and independent position, that "while Abduh adopts the Mu'tazili position of interpretation (a metaphorical, figurative views), Rida follows the "Ash'ariyah in their idea of God having limbs without howness." 107

\section{Conclusion}

This paper had briefly demonstrated the major influences of Muhammad Abduh on Muhammad Rashid Rida. Abduh had exercise lasting and far-reaching influences on Rida in the realm of tafsir, hadith, jurisprudence, theology and journalism. Rida's principal works such as Tarikh al-Ustadh al-Imam al-Shaykh Muhammad Abduh and Tafsir al-Manar critically expounded his ideas and strengthened his arguments and reinforced his great legacy and struggle for reform and renewal. The reform aspiration was rigorously resonated by the great efforts of Rida that became a critical foundation and important milestones for renewed aspiration for the Muslim umma to continue underscore Islamic revival in modern times.

\footnotetext{
103 P.J. Stewart, Unfolding Islam (London: Garnet Publishing, 1995), 194, Hamid Enayat, Modern Islamic Political Thought (Austin: University of Texas Press, 1982), 8.

${ }^{104}$ Ignaz Goldziher, Die Richtungen der Islamischen Koranauslegung (Leiden: E.J. Brill, 1952), 325, Harun Nasution, 1968, 15, op.cit.

105 P.J. Stewart, 1995, 194, op.cit., Hamid Enayat, 1982, 8, op.cit., Harun Nasution, 1968, 16, op.cit.

106 Uthman Amin, 1953, 168, op.cit.

107 Rashid Rida, Tafsir al-Manar (Beirut: Dar al-Kutub al-'Tlmiyyah, 1999), 3/201, Harun Nasution, 1968, 16, op.cit.
} 


\section{References}

A. Athaillah. (2006). Rasyid Ridha: Konsep Teologi Rasional dalam Tafsir al-Manar. Jakarta: Penerbit Erlangga.

Abd al-Qadir al-Zimamah, et al. (1997). Mu'jam Tafsir al-Qur'an alKarim. N.p.: Mansyurat al-Munazzamah al-Islamiyyah li alTarbiyyah wa al-'Ulum wa al-Thaqafah (ISESCO).

Abdin Chande. (2004). Symbolism and Allegory in the Qur'an: Muhammad Asad's Modernist Translation. Islam and ChristianMuslim Relations, 15:1, 79-89.

Abdullah Mahmud Syahatah. (1984). Manhaj al-Imam Muhammad 'Abduh fi Tafsir al-Qur'an al-Karim. Cairo: Matba'ah Jami'ah alQahirah.

Abdullah Saeed. (2008). The Qur'an An Introduction. Oxford: Routledge.

Ahmad Bazli Shafie. (2004). The Educational Philosophy of al-Shaykh Muhammad Abduh. Kuala Lumpur: International Institute of Islamic Thought and Civilization.

Al-Dhahabi, Muhammad Husayn. (1976). Al-Tafsir wa'l-Mufassirun. Cairo: Dar al-Kutub al-Hadithah.

Al-Dhahabi, Muhammad Husayn. (1989). Al-Tafsir wa'l-Mufassirun. Cairo: Maktabah Wahbah.

Al-Qaradawi, Yusuf. (1992). Al-Fatwa bayna al-Indibat wa al-Tashayyu' (3rd ed.). Cairo: Dar al-Sahwa.

Al-Muhtasib, 'Abd al-Majid 'Abd al-Salam. (1982). Ittijahat al-Tafsir fi al'Asr al-Rahin. Beirut: Dar al-Bayariq.

Al-Rumi, Fahd b. 'Abd al-Rahman b. Sulayman. (2002). Ittijahat al-Tafsir fi al-Qarn al-Rabi' 'Ashr (4th ed.). Riyad: Maktabah al-Rushd.

Albert Hourani. (1967). Arabic Thought in the Liberal Age 1798-1939. London: Oxford University Press.

Anwar al-Jundi. (1977). Tarajim al-A'lam al-Mu'asirin fi al-'Alam alIslami. Cairo: Maktabah al-Anglo.

B. Michel, Moustapha Abdel Razik (1925). Introduction sur la vie et les idees du Cheikh Mohammed Abdou, introduction to Rissalat al Tawhid: expose de la religion musulmane. Paris: P. Geuthner.

Caesar E. Farah. (1994). Islam: Beliefs and Observances. New York: Barron's Educational Series.

C.C. Berg. (1973). Indonesia. In H.A.R. Gibb, (ed.), Whither Islam? A Survey of Modern Movements in the Moslem World. New York: AMS Press.

Charles C. Adams. (1933). Islam and Modernism in Egypt: A Study of the Modern Reform Movement Inaugurated by Muhammad 'Abduh. London: Oxford University Press. 
Fazlur Rahman. (1996). The Impact of Modernity on Islam. Islamic Studies, $5,2$.

Felicitas Opwis. (2004). Changes in Modern Islamic Legal Theory: Reform or Reformation? In Michaelle Browers and Charles Kurzman, (eds.), An Islamic Reformation? (pp. 28-53). Lanham: Lexington Books.

H.A.R. Gibb. (1964). Mohammedanism: An Historical Survey. ( $2^{\text {nd }}$ ed.). London: Oxford University Press.

Hamid Enayat. (1982). Modern Islamic Political Thought. Austin: University of Texas Press.

Harun Nasution. (1968). The Place of Reason in 'Abduh's Theology: Its Impact on his Theological System and Views. Ph.D Thesis, Institute of Islamic Studies, McGill University.

Hunt Janin. (2005). The Pursuit of Learning in the Islamic World, 6102003. North Carolina: McFarland.

Iftitah Jafar. (1998). Modern Qur'anic Exegesis: A Comparative Study of the Methods of Muhammad 'Abduh and Muhammad Rashid Rida. M.A. Thesis, Institute of Islamic Studies, McGill University. Ibrahim Abu Bakar. (1992). Islamic Modernism in Malaya as Reflected in Hadi's Thought. Ph.D. Thesis, Institute of Islamic Studies, McGill University, Montreal.

Ignaz Goldziher. (1952). Die Richtungen der Islamischen Koranauslegung. Leiden: E.J. Brill.

Jane Dammen McAuliffe. (1991). Qur'anic Christians: An Analysis of Classical and Modern Exegesis. Cambridge: Cambridge University Press.

J. Jomier. (1954). Le Commentaire Coranique du Manar. Paris: G.P. Maisonneuve \& Cie.

J. Jomier. (1991). Al-Manar. Encyclopaedia of Islam 2, VI, 361.

J.M.S. Baljon. (1968). Modern Muslim Koran Interpretation (1880-1960). Leiden: E.J. Brill.

Kosugi Yasushi. (2006). Al-Manar revisited: the "lighthouse" of the Islamic revival. In Stephane A. Dudoignon, Komatsu Hisao, Kosugi Yasushi (Eds.), Intellectuals in the Modern Islamic World Transmission, Transformation, Communication. London and New York: Routledge.

Kurzman, Charles. (ed.). (2002). Modernist Islam 1840-1940. Oxford: Oxford University Press.

Osman Amin. (1995). The Modernist Movement in Egypt. In Islam and the West: Proceedings of the Harvard Summer School Conference on the Middle East, July 25-27. 
Mahmoud Ayoub. (1984). The Qur'an and Its Interpreters, vol. I. Albany: State University of New York Press.

Malcolm Kerr. (1966). Islamic Reform: The Political and Legal Theories of Muhammad 'Abduh and Rashid Rida. Berkeley, Los Angeles: University of California Press.

M. Quraish Shihab. (1994). Rasionalitas al-Qur'an: Studi Kritis atas Tafsir al-Manar. Bandung: Pustaka Hidayah.

Mustaffa Abdullah et. al (2012). Sayyid Muhammad Rasyid Rida's Influence on Tafsir Studies in Malaysia. Middle-East Journal of Scientific Research, 12:6, 760-766.

Qutb, Sayyid. (1980). Khasa'is al-Tasawwur al-Islami wa Muqawwimatuh. Beirut: Dar al-Shuruq.

Rida, Rashid. (1901). Muhawarat al-Muslih wa al-Muqallid. Al-Manar 4, 209-210.

(1904). Tarikh al-Ustadh al-Imam Muhammad 'Abduh. Cairo: Matba'ah al-Manar.

(1909). Majallat al-Manar, vol. I, (2 ${ }^{\text {nd }}$ ed.). Cairo: al-Manar.

(1923). Al-Khilafah, aw al-Imamah al-'Uzma. Cairo: al-Manar.

(1923). Ahl al-hall wa al-'aqd fi hadha al-zaman (a chapter in

his treatise on the Caliphate). Al-Manar 24, 59-60.

(1931). Tarikh al-Ustadh al-Imam ash-Shaykh Muhammad

'Abduh. Cairo: Matba'ah al-Manar.

(1947). Tafsir al-Qur'an al-Hakim al-mushtahar bi ism Tafsir al-Manar. Cairo: Dar al-Manar.

(1972). Tafsir al-Manar. Cairo: Dar al-Hay'a al-Misriyya al'Amma li-l-Kitab. (1999). Tafsir al-Manar. Beirut: Dar al-Kutub al-'Ilmiyyah.

Ryuichi Funatsu. (2006). Al-Kawakibi's Thesis and its Echoes in the Arab World Today. Harvard Middle Eastern and Islamic Review 7, 1-40.

P.J. Stewart (1995). Unfolding Islam. London: Garnet Publishing.

Uthman Amin (1953). Muhammad Abduh, translated by Charles Wendell. Washington, DC: American Council of Learned Societies. 